\title{
Examining emotions linked to live chat services: The role of e-service quality and impact on word of mouth
}

\author{
Lova Rajaobelina $^{1} \cdot$ Isabelle Brun $^{2} \cdot$ Nour Kilani $^{1} \cdot$ Line Ricard $^{1}$
}

Received: 24 January 2021 / Revised: 5 August 2021 / Accepted: 21 September 2021 / Published online: 5 October 2021

(c) The Author(s), under exclusive licence to Springer Nature Limited 2021

\begin{abstract}
The purpose of this article is twofold: (1) to investigate the emotions experienced by banking customers when using live chat services and their impact on positive word-of-mouth intentions; and, (2) to identify which dimensions of e-service quality (accessibility, customer service and support, perceived security/privacy and design) impact these emotions. A survey was conducted with 682 members of a Web-based panel. Findings demonstrate that emotions, both positive and negative, significantly impact word of mouth. Results further reveal that customer service and support followed by design of live chat services mostly influence consumer emotions. On a practical level, the recommendations provided will improve consumer experience and encourage consumers to use live chat services. This is all the more important since such services are now part of the promotion and contribution of a sustainable mode of consumption that is accessible to all.
\end{abstract}

Keywords Live chat services $\cdot$ Emotions $\cdot$ Word of mouth $\cdot$ e-service quality $\cdot$ Banking services $\cdot$ Live support system, realtime communication

\section{Introduction}

Financial institutions invest in Web strategies to foster stronger, more personalized relationships with their customer base and to elicit positive consumer behaviour such as loyalty and word of mouth (Boateng and Narteh, 2016; Liang and Chen, 2009). Accordingly, most banking websites today incorporate online customer service tools such as e-mail, e-forms, help menus and/or sections detailing frequently asked questions (FAQs). While these increasingly standardized tools can help answer basic consumer queries, they do not enable financial institutions to differentiate themselves from their sectoral counterparts. Their functionalities do not operate in real time and may lack in

The authors wish to thank the Social Sciences and Humanities Research Council of Canada (SSHRC) and the Fintech Research Chair AMF-Finance Montreal of the Université du Québec à Montréal for their financial contributions to the project

Lova Rajaobelina

rajaobelina.lova@uqam.ca

1 Département Marketing, Université du Québec À Montréal, Case postale 8888, succ. Centre-ville, Montreal, QC H3C 3P8, Canada

2 Université de Moncton, Moncton, Canada retroactivity (Elmorshidy, 2013). How then, using virtual settings intended to take convenience and connectivity to an entirely new level (e.g. users able to access information at any time, from any location), can the banking industry capitalize fully on the different opportunities fostered by technological advancement?

Luo et al. (2011) point to interaction as one of the characteristics of the online virtual experience that most promotes behavioural intentions to visit websites and make purchases while building customer loyalty. Accordingly, businesses, including financial institutions (Elmorshidy et al., 2015), have adopted online social interaction functionalities such as online agents, both human and computerized (Shank, 2014). More precisely, live chat services differ from chatbot services in that the former represent human-to-human interactions through instant messaging and that the latter are computer-mediated communications which transfer automated responses to the consumer. Live chat services which provide for real-time synchronized communications between customers and customer service representatives (McLean and Osei-Frimpong, 2017) constitute invaluable customer service tools in Web-based environments. They enable customers to obtain answers more quickly than via e-mail and to receive more personalized responses and content than would be available through a frequently asked questions (FAQs) 
segment or even chatbot inquiries. This type of technology is even more important in a post-pandemic context, where banking consumers are urgently seeking easy and fast access to online customer service and support when they need it as they are prone to be anxious about their personal finances (Mehta 2020), hence the need to better understand the impact of live chat service use on consumer responses and behaviours.

The majority of research into human-technology interaction focuses on information processing and consumer cognitive responses (e.g. satisfaction in Chung et al. (2020), Lew et al. (2018); Mero (2018)). In choosing to concentrate on the cognitive aspects of chatbot use and evaluation, researchers leave behind other important concepts such as emotions (Jokinen, 2015). Indeed, while emotions and affective state are shown to play a dominant role in online customer experience (e.g. Rose et al., 2012), only few researchers have investigated the affective state of customers in live chat service settings (e.g. Chen et al. (2018) who examine emoticons) or examined the importance of emotions in a utilitarian context such as online banking (Rychalski and Hudson, 2017). Research to date nonetheless substantiates the study of emotions as crucial to understanding consumer behaviour (Bagozzi et al., 1999; Das and Varshneya, 2017) since humans are not purely rational beings. Customers have emotional needs and seek, through consumption, a combination of emotional and utilitarian benefits (Das and Varshneya, 2017).

Understanding emotions and the factors that impact them in environments such as live chat services commands growing attention given the ever increasing use of technology by financial institutions. Indeed, eliciting positive emotions in consumers is critical given notable consumer impact on technology use (Hibbeln et al., 2017), product/service evaluation (Kim and Gupta 2012), satisfaction (Dubé-Rioux, 1990; Oliver 1993; Westbrook, 1987), purchase intentions (Koo and Ju 2010), loyalty (Hibbeln et al., 2017), impulse purchases (Ozen and Engizek 2014) and word of mouth (Ladhari, 2007; Schnebelen and Bruhn 2018; Sweeney et al. 2012). In this study, an examination of the latter could prove of interest in the light of business investment in interactive functionalities such as live chat services and the adoption of new technology to enhance positive word of mouth (Tsai and Compeau, 2010). The first objective of this study is therefore to investigate the impact of positive and negative emotions on customer positive word-of-mouth intentions respecting live chat services in the financial sector.

Several other important issues relating to emotions elicited during live chat services also deserve to be addressed. For example, in a live chat services context, which elements of the service environment contribute most to foster positive emotions? Which elements help most to avoid negative emotions? Information of the like could help financial institutions ensure the best design, development and implementation of live chat service tools intended to generate optimal emotional experiences. The service environment indeed assuredly plays a vital role in service delivery in the light of an evident capacity to foster pleasurable emotional reactions, while strengthening customer perceptions and retention (Baker et al., 2002; Bitner, 1992; Lin and Liang, 2011; Sherman et al., 1997). To comprehend more fully the impact of the service environment in the context of live chat services, we use an extensively investigated concept in the service literature, namely e-service quality. In consumer behaviour research, consumer-assessed e-service quality has rapidly developed into a driver of online consumer satisfaction (Bressolles and Nantel 2008; Parasuraman et al., 2005; Sharma and Lijuan, 2015) including in the financial industry (Amin, 2016). E-service quality is also identified as key for enhancing website effectiveness (Bressolles 2006), facilitating the online customer conversion process and loyalty (Dai et al. (2011); Shankar and Jebarajakirthy (2019), in banking). Hence, the second objective of this research is to identify which dimensions of e-service quality (accessibility, customer service and support, perceived security/privacy and design) impact positive and negative customer emotions respecting live chat services in the financial industry.

All things considered, an examination of these two research objectives in an online live chat services context should yield interesting results, while contributing to the literature in the field and providing sound direction for practitioners. In the upcoming section, we present a literature review and develop a series of hypotheses, then follows an outline of research methodology, data analysis procedures and findings. The concluding section proposes a discussion of findings, as well as study limitations and directions for future research.

\section{Literature review and hypotheses development}

\section{Live chat services}

Live chat services enable consumers to ask questions and receive information from human representatives (McLean and Osei-Frimpong, 2017) and address concerns and complaints in a Web-based environment (Elmorshidy et al., 2015). More specifically, through instant messaging (i.e. instantaneous transmission of text-based messages) between senders and receivers (Elmorshidy, 2013; Elmorshidy et al., 2015; Xu, 2016), live chat services provide an opportunity for customers and service employees/experts to interact. These services bypass more traditional methods such as e-mail and e-forms, with questions and concerns answered on the spot in real time (Elmorshidy et al., 2015). 
They also allow for more personalized interaction than that obtained using chatbot capability which generates automated responses through artificial intelligence (McLean and OseiFrimpong, 2019). Although reactions of human and computerized agents may be similar, obvious differences readily detected by consumers alter sensory perceptions and physical cues (Shank, 2014).

Live chat services continue to gain in popularity because they are viewed as cost-effective customer service tools which provide immediate responses, increase social interaction, enhance personalization and promote consumer trust, while reducing perceptions of risk associated with online purchases (Elmorshidy, 2013; Elmorshidy et al., 2015). Live chat services also constitute an effective service recovery tool (McLean, 2017). For customers, they are not only more and more prevalent but also useful. When asked which channels US customers prefer when communicating with companies, $44 \%$ of respondents cite live chat services (eMarketer, 2019a). Ranking at the same level as e-mails but behind the telephone (eMarketer, 2019b), these services fulfil a growing need and enable Web users to collaborate, communicate and connect in online social settings (Elmorshidy et al., 2015; McLean, 2017). Chattaraman et al. (2012) highlight search support, decision support and navigational/ procedural support as three key uses of live chat service technology. Customers expect and seek out the same type of service online as they receive offline (McLean and OseiFrimpong, 2019). For example, 'those who have an unsuccessful search expect to be able to seek online support from a company representative the same way as they would do in the offline environment' (McLean, 2017; p. 657). The study by the latter author evidences the fact that website searches are often abandoned by customers who would appreciate online support but cannot locate it, underscoring the importance of Web-based customer support. In an era in which differentiation is challenging and competition fierce, live chat services are essential as they attract more consumers to websites (Kim et al., 2007), enhance customer experience (McLean and Osei-Frimpong, 2017) and improve customer relationships (McLean and Osei-Frimpong, 2019). Prior research probes the impact of live chat service use, intent to return to a website $(\mathrm{Xu}, 2016)$ and patronage intentions in relation to virtual agents (Etemad-Sajadi, 2014). However, further research is warranted to understand more properly the affective state of consumers when using such services, especially given consistent research-based demonstration of the importance of emotions in comprehending consumer behaviour.

\section{Emotions}

Holbrook and Hirschman (1982) were the first to include emotions as a determining variable of consumer behaviour.
Since then, several other authors (e.g. Bagozzi et al., 1999; Ladhari, 2007; Mattila and Enz, 2002; Richins, 1997; Westbrook and Oliver 1991; Wu and Wang, 2017) have manifested an interest in emotions as a predictive element of consumer behaviour (purchase and word-of-mouth intentions). To enhance consumer behavioural intentions, previous research underscores the importance of companies prioritizing and strengthening the affective components of service as the latter exercise greater influence than their cognitive component counterparts (Chiu and Wu, 2002). Fernandes and Proença (2013, p. 49) demonstrate that the satisfaction of consumer emotional motivations leads to 'higher forms of dedication to the provider' than does the satisfaction of cognitive motivations. Similarly, Magids et al. (2015) find that customers emotionally connected to a brand are more valuable than those reported to be very satisfied. More recently, emotions have been shown to play an essential role in rational thinking and reasoning systems, thereby sparking the interest of researchers in neuroscience and cognitive psychology (Lee et al., 2019).

For the purpose of this study, the definition of 'emotion' advocated by Bagozzi et al. (1999, p. 184) is retained:

A mental state of readiness that arises from cognitive appraisals of events or thoughts, has a phenomenological tone, is accompanied by physiological processes, is often expressed physically (e.g. in gestures, posture and facial features), and may result in specific actions to affirm or cope with the emotion, depending on its nature and meaning for the person having it.

Emotions, conscious or unconscious (Bagozzi et al., 1999) and linked to affect-laden judgments or beliefs (Rousi and Renko, 2020), are deemed central to action taken by consumers (Bagozzi et al., 1999; Gaur et al., 2014; Huang, 2001; Lin and Liang, 2011). These emotions are short-term sentiments of positive or negative valence (Bagozzi et al., 1999; Erevelles, 1998; Haavisto and Sandberg, 2015; Richins, 1997). Positive emotions include happiness and joy, whereas negative emotions can extend to fear and anger (Izard 1977; Plutchik 1980; Roseman, 1991). Some authors (e.g. Haavisto and Sandberg, 2015) observe negative emotions to be stronger and more readily present than positive emotions in certain instances (e.g. discussion forums). The valence approach, which entails measuring both positive and negative emotions (Laros and Steenkamp, 2005), is widely used to assess consumer emotional responses to service experiences (Jang and Namkung, 2009; Lo and Wu, 2014; Ou and Verhoef, 2017; Peng et al., 2017; Ribeiro and Prayag, 2018).

Emotions are typically elicited by events, objects or individuals through the likes of service encounters or interaction with service personnel, salespersons and in-store features (Ladhari et al., 2017), thereby substantiating that 
the environment plays a vital role in an individual's affective state. Indeed, based on the Environmental Psychology Theory which focuses on the interplay between individuals and their surrounding, ${ }^{1}$ Mehrabian and Russel (1974) figure amongst the first to examine how atmospheric cues impact emotional arousal and responses. In their S-O-R (stimulus-organism-response) framework, they establish that the stimulus (environment) influences the organism (individual's internal state, such as emotions) which evokes a response (behaviour). Donovan and Rossiter (1982), who demonstrate that the paradigm may be applied to the retail sector, have inspired many marketing researchers to use their theory in subsequent studies such as the one by Loureiro and Roschk (2014) who find that cues can be impactful in both offline and online environments.

A number of authors investigate consumer emotions in an e-commerce context (e.g. Balaji et al., 2017; Bui and Kemp, 2013; Éthier et al., 2008; Haavisto and Sandberg, 2015; Kafetsios et al., 2017; Rose et al., 2012) and substantiate beyond a doubt that individuals do experience emotions as they browse websites (Balaji et al, 2017; Éthier et al., 2008). Emotions experienced by browsers are deemed similar to those experienced in a physical context (Éthier et al., 2008).

Given that some previous studies assess the effect of service quality on positive and negative emotions (Chen et al., 2015; Peng et al., 2017; Ribeiro and Prayag, 2018), an exploration of the impact of e-service quality on emotions in a live chat services environment appears opportune.

\section{Word of mouth (WOM)}

Word of mouth has proved a leading research topic in the marketing literature (Martin and Lueg, 2013), with the advent of technology (e.g. Internet, social media) significantly impacting the concept (Chen et al., 2014; Ismagilova et al., 2020; Luonila et al., 2016). Omnipresent and widespread, eWOM enhances the power of peer-to-peer communications among consumers (Dellarocas et al., 2007; Kasabov, 2016).

Word of mouth is defined as 'an informal verbal communication occurring in person, by telephone, e-mail, mailing list or any other means of communication with regard to a good or service' (Goyette et al., 2010, p. 9). A recommendation source may be either personal or impersonal and deemed independent of commercial influence (Litvin et al., 2008). People proffer positive or negative opinions about a company product or service (Goyette et al., 2010), hence the terms positive or negative word of mouth. Accordingly, some authors (e.g. Goyette et al., 2010; Packard and Berger, 2017) define positive word of mouth as the action of

\footnotetext{
${ }^{1} \mathrm{https} / / /$ positivepsychology.com/environmental-psychology/.
}

recommending a company's services to others. The approach chosen for the study at hand is consistent with the foregoing definition.

Positive word of mouth constitutes a valued ally. Consumers use it to fulfil a need for information and reduce the perceived risk and uncertainty surrounding a consumption decision (Mangold et al., 1999; Murray 1991). Word of mouth represents a leading resource for sustaining brand image, market position and customer relations (Luonila et al., 2016). Word of mouth can also exert an influence greater than either advertising or salespersons (HennigThurau et al., 2004; Packard et al., 2016; Steffes and Burgee, 2009). Positive word of mouth further helps businesses reduce marketing costs, boost sales and profits, and attract and retain customers (Lin and Lu, 2010; Trusov et al., 2009). Lastly, following interaction with service staff, the study by Wang (2009) demonstrates that the development of positive emotions leads to greater customer patronage intentions (e.g. intentions to recommend, purchase or continue shopping) given increased satisfaction and a more positive attitude towards the brand.

In the e-commerce literature, emotions are shown to influence behavioural intentions, including the prospective use of online stores and formulation of recommendations to others (Koo and $\mathrm{Ju}, 2010$ ).

It is interesting to consider the valence of emotions (Laros and Steenkamp, 2005; Phillips and Baumgartner, 2002). The combination of positive and negative emotions more accurately reflects a person's attitude and represents the most popular conceptualization of emotions (Laros and Steenkamp, 2005). Indeed, positive and negative emotions are independent variables activated by different stimuli and may lead to different cognitive and behavioural responses (Lee et al., 2011; Ou and Verhoef, 2017), hence the necessity of treating them as two independent constructs, rather than two opposite ends of a continuum of the same dimension (Lee et al., 2011; Zhao et al., 2018). To the best of our knowledge, positive and negative emotions have never been studied together in the context of live chat services. From a managerial perspective, and given the independent nature of these variables, studying emotion valence will allow managers to understand which variables prompt positive emotions and which variables avoid or at least mitigate negative emotions (Ou and Verhoef, 2017).

When using products or services such as live chat services, consumers who experience stronger positive emotional responses would be more inclined to share information regarding these products or services (Alhidari et al., 2015; Ismagilova et al., 2020). Hence, our first hypothesis:

H1 Positive emotions linked to live chat services positively impact positive word of mouth. 
Consumers who experience negative emotions such as frustration or anxiety may sense that they risk losing out by using live chat services. Such emotions understandably diminish consumer intentions, behaviours and inclination to purchase/talk about products or services, especially in an online context (Gemar et al. 2019). Accordingly, the following hypothesis is proposed:

H2 Negative emotions linked to live chat services negatively impact positive word of mouth.

\section{E-service quality and impact on emotions}

Service quality is a useful strategic management tool (Hemmasi et al., 1994) since it exerts an impact on business profits and market shares (Parasuraman et al., 1991). Furthermore, a number of authors demonstrate the importance of service quality in a Web-based context (e.g. Barnes and Vidgen, 2003; Bressolles 2006; Kao and Lin, 2016; Lien et al., 2017; Parasuraman et al., 2005; Wolfinbarger and Gilly, 2003; Yoo and Donthu, 2001) and in e-banking (e.g. Amin, 2016; Ladhari and Leclerc, 2013; Raza et al., 2020). In an environment in which the means of interacting and conducting transactions continue to evolve, e-service quality, which is to say the 'quality of service customers experience in online channels', is critical (Blut et al., 2015) given the impact on consumer trust (Al-Nasser et al., 2013; Kao and Lin, 2016), satisfaction (Collier and Bienstock, 2006; Dai et al., 2011; Kao and Lin, 2016; Kim and Kim, 2020) and loyalty (Dai et al., 2011; Kim and Kim, 2020; Shankar and Jebarajakirthy, 2019).

To understand more fully customer emotions-positive and negative-in a live chat services context, the impact of four dimensions of e-service quality derived from the topical literature is examined, namely accessibility, customer service and support, perceived security/privacy and design. Albeit there exists no consensus respecting the number and nature of dimensions of e-service quality (Ladhari, 2010), the dimensions retained for this study are those which recur most readily in the literature (Blut, 2016; Jun et al., 2004; as well as Shankar and Jebarajakirthy, 2019 in the financial industry). (Please see Table 1.) These dimensions accurately capture the essence of online chat services and acknowledge the latter as a technology-based tool (hence the importance of accessibility, perceived security/privacy and design) with a strong human presence given that communication takes place with an agent (hence the interest of including customer service and support).

Furthermore, Kim and Lennon (2013) present service quality as an antecedent of the emotions experienced online by consumers. Also, Hart and Sutcliffe (2019) point to a link between service quality in relation to interactive products (iPads) and emotions (positive and negative). It is therefore interesting to investigate whether these elements of online service quality are also important in the relatively recent online live chat services context.

The following paragraphs present the hypotheses and identify the potential impact of each dimension of e-service quality on consumer emotions.

The notion of accessibility refers to ease of use, convenience and adaptability (Giraud et al., 2018; Rodríguez et al., 2017). Drawing inspiration from the conceptualization of accessibility in a Web-based context as suggested by Martins et al. (2017), accessible live chat services refer to services that are easy to locate, easy to use, easy to understand and readily compatible with different technological devices. Ease of use has been shown to impact a virtual agent's hedonic value (Etemad-Sajadi, 2014). Several authors also argue that ease of use enhances satisfaction in e-banking (Casaló Ariño et al., 2008; Liao and Cheung, 2008), a notion closely allied with emotions (Rychalski and Hudson, 2017). Hence, the following hypotheses:

H3 Accessibility linked to live chat services impacts emotions.

H3a Accessibility linked to live chat services positively impacts positive emotions.

Conversely, some authors claim that a lack of accessibility leads to negative emotions. For example, Lee et al. (2011) evidence that sellers who are inaccessible or who ignore their customers induce negative emotions in the latter such as frustration, dissatisfaction and annoyance. Habib and Qayyum (2018) demonstrate that ease of navigation, organization and availability of requisite information on an e-commerce website contribute to the development of positive emotional responses (e.g. pleasantness of mood and arousal), whereas a website that is difficult to use leads to an unfavourable emotional response. Thus, the next hypothesis is presented:

H3b Accessibility linked to live chat services negatively impacts negative emotions.

Customer service and support relate to services offered to customers to fulfil their needs and ensure timely responses to their questions, returns or complaints (Blut et al., 2015). These services notably require the input of competent, caring individuals capable of responding quickly to customer requests in the banking sector (Shankar and Jebarajakirthy 2019). Personalized online services are equally essential (Verhagen et al., 2014). In interactions with service agents, consumers generally expect agents to exhibit certain characteristics (e.g. benevolence, competence and courtesy). According to emotional contagion theory, positive emotion 
Table 1 Dimensions of e-service quality

\begin{tabular}{|c|c|c|c|c|c|c|c|c|}
\hline & Fulfilment & $\begin{array}{l}\text { Compe- } \\
\text { tence and } \\
\text { efficiency }\end{array}$ & Reliability & $\begin{array}{l}\text { Secu- } \\
\text { rity/ } \\
\text { privacy }\end{array}$ & $\begin{array}{l}\text { Content and } \\
\text { information }\end{array}$ & $\begin{array}{l}\text { Aestheti- } \\
\text { cism and } \\
\text { design }\end{array}$ & $\begin{array}{l}\text { Accessibil- } \\
\text { ity/ ease of } \\
\text { use }\end{array}$ & $\begin{array}{l}\text { Customer service/ } \\
\text { personalization/ } \\
\text { interaction }\end{array}$ \\
\hline Yoo and Donthu (2001) & & & & $\mathrm{X}$ & & $\mathrm{X}$ & $X$ & \\
\hline Trocchia and Janda (2003) & & $\mathrm{X}$ & & $\mathrm{X}$ & $\mathrm{X}$ & $\mathrm{X}$ & $\mathrm{X}$ & \\
\hline Cai and Jun (2003) & & & $\mathrm{X}$ & $X$ & & $\mathrm{X}$ & & $\mathrm{X}$ \\
\hline Santos (2003) & & $\mathrm{X}$ & $\mathrm{X}$ & $\mathrm{X}$ & $\mathrm{X}$ & $\mathrm{X}$ & $\mathrm{X}$ & \\
\hline Iwaarden et al. (2003) & & & $\mathrm{X}$ & $X$ & & $\mathrm{X}$ & & $\mathrm{X}$ \\
\hline Barnes and Vidgen (2003) & & & & & $\mathrm{X}$ & $\mathrm{X}$ & & $\mathrm{X}$ \\
\hline Jun et al. (2004) & & & $\mathrm{X}$ & $X$ & $X$ & & $X$ & $\mathrm{X}$ \\
\hline Webb and Webb (2004) & & & $\mathrm{X}$ & $X$ & & & $X$ & $\mathrm{X}$ \\
\hline Parasuraman et al. (2005) & $\mathrm{X}$ & $\mathrm{X}$ & & $\mathrm{X}$ & & & $\mathrm{X}$ & \\
\hline Bauer et al. (2006) & $\mathrm{X}$ & & $\mathrm{X}$ & & & $\mathrm{X}$ & & $\mathrm{X}$ \\
\hline Bressolles (2006) & & & $\mathrm{X}$ & $X$ & $X$ & $\mathrm{X}$ & $X$ & $\mathrm{X}$ \\
\hline $\begin{array}{l}\text { Collier and Bienstock } \\
\text { (2006) }\end{array}$ & $\mathrm{X}$ & $\mathrm{X}$ & & $\mathrm{X}$ & $\mathrm{X}$ & & $\mathrm{X}$ & \\
\hline Piercy (2014) & $\mathrm{X}$ & & & $\mathrm{X}$ & & $\mathrm{X}$ & & \\
\hline $\begin{array}{l}\text { Ladhari and Leclerc } \\
(2013)^{*}\end{array}$ & & & & & $\mathrm{X}$ & $\mathrm{X}$ & $\mathrm{X}$ & $\mathrm{X}$ \\
\hline Yapp et al. (2014) & & & $\mathrm{X}$ & $\mathrm{X}$ & $\mathrm{X}$ & & & $X$ \\
\hline Blut et al. (2015) & $\mathrm{X}$ & & & $X$ & & $\mathrm{X}$ & & $\mathrm{X}$ \\
\hline Zemblyté (2015) & $\mathrm{X}$ & & & $\mathrm{X}$ & & & $\mathrm{X}$ & $\mathrm{X}$ \\
\hline Blut (2016) & $\mathrm{X}$ & & & $X$ & & $\mathrm{X}$ & $X$ & $\mathrm{X}$ \\
\hline Kao et Lin (2016) & & $\mathrm{X}$ & $\mathrm{X}$ & & $\mathrm{X}$ & & $\mathrm{X}$ & \\
\hline $\operatorname{Amin}(2016)^{*}$ & & & & $\mathrm{X}$ & $\mathrm{X}$ & & $X$ & $X$ \\
\hline Lien et al. (2017) & & & $\mathrm{X}$ & & & & $X$ & $\mathrm{X}$ \\
\hline $\begin{array}{l}\text { Goutam and } \\
\text { Gopalakrishnab (2018) }\end{array}$ & $\mathrm{X}$ & $\mathrm{X}$ & & $\mathrm{X}$ & & & $\mathrm{X}$ & \\
\hline $\begin{array}{l}\text { Shafiee and Bazargan } \\
\text { (2018) }\end{array}$ & & & & $\mathrm{X}$ & & & $X$ & \\
\hline $\begin{array}{l}\text { Shankar and Jebarajakirthy } \\
(2019)^{*}\end{array}$ & & & $\mathrm{X}$ & $\mathrm{X}$ & & $\mathrm{X}$ & & $\mathrm{X}$ \\
\hline Raza et al. (2020)* & & & $\mathrm{X}$ & $X$ & & $\mathrm{X}$ & $X$ & $\mathrm{X}$ \\
\hline TOTAL & 8 & 6 & 12 & 20 & 10 & 14 & 17 & 16 \\
\hline
\end{tabular}

*Studies in a banking context

displayed by an employee can be positively associated with positive emotion elicited in a customer (Lin and Liang, 2011). Manifestations of positive staff emotions such as a greeting, an open-ended question like 'How are you today?' or a thank you at the end of a conversation correlate with positive client emotions (Wang, 2009). A cultivated sense of salesperson empathy similarly generates positive emotions such as warmth, fulfilment and happiness (Lee et al., 2011). Indeed, when customer expectations are met, customers develop positive affection reactions towards agents (Cohen-Charash and Spector, 2001; Turel and Connelly, 2013). Accordingly, we propose that:

H4 Customer service and support linked to live chat services impact emotions.
H4a Customer service and support linked to live chat services positively impact positive emotions.

Conversely, when customer expectations are not met (e.g. agents found to be incompetent or not customerfocused), negative emotions such as anger can manifest (Harris, 2013). For Zhao et al. (2018), employees who successfully deliver their in-role behaviour (e.g. performance consistent with customer expectations) generate positive emotions in customers and mitigate any negative emotions. More recent findings from in-travel context research suggest that the dimension of interactional justice (e.g. positive employee attitudes and behaviours, empathy and apologies) generates positive emotions greater than those generated by monetary compensation, while mitigating 
negative emotions (Xu et al., 2019). We therefore hypothesize as follows:

H4b Customer service and support linked to live chat services negatively impact negative emotions.

Security issues in e-commerce relate to the capacity of e-businesses to safeguard their online transaction systems. Security threats include the destruction, disclosure and modification of data, denial of service, and/or fraud and abuse (Kalakota and Whinston, 1996). Goodwin (1991) defines perceived privacy as 'the customer's perception of exercising control over the following: (1) the presence of other people in the environment during a market transaction or consumption behaviour; and, (2) the dissemination of information related to or provided during such transactions or behaviours to those who were not present' (p. 152). Privacy and security are that much more important in the banking sector as customers associate a certain degree of vulnerability and risk with financial services (Moin et al., 2015). This study considers privacy and security concerns to be a single construct in the sense advocated by McCole et al. (2010) as well as Jahangir and Begum (2007) in the financial industry. Indeed, given the undeniable link between privacy and security, Web-based consumers are seldom able to differentiate between the two (McCole et al., 2010). Chung and Shin (2010) find perceived security to impact satisfaction. In addition to generating satisfaction, the perceived security and privacy of a financial website, or any other type of website, positively influence user trust (e.g. Al-Sharafi et al., 2018; Carlos Roca et al., 2009; Damghanian et al., 2016; Flavián and Guinalíu 2006). Lee et al. (2011) further find that that when the seller is perceived as trustworthy, customers feel safe, content, comfortable and pleased. Hence, the following hypotheses:

H5 Perceived security/privacy linked to live chat services impacts emotions.

H5a Perceived security/privacy linked to live chat services positively impacts positive emotions.

Conversely, whenever customers perceive a salesperson or website to be untrustworthy, they may feel unhappy, frustrated and angry (Lee et al., 2011). Since perceptions of privacy and security relate closely to trust (Flavián and Guinalíu 2006), we hypothesize as follows:

H5b Perceived security/privacy linked to live chat services negatively impacts negative emotions.

Design and aesthetics have been shown to be of utmost importance regarding human-computer interaction, in some cases even more so than usability (Lin, 2013). The present study focuses on design linked to live chat services. The concept of design refers to the richness of the environment's representation which is determined by characteristics of form, notably graphics, images, animation, videos and so on (Stremtan and Muntean 2008). These elements combine to create a virtual atmosphere, attract consumer attention and elicit favourable attitudes (Moore et al., 2005). Applying the S-O-R paradigm (Mehrabian and Russel 1974) to online stores, website stimuli are found to influence consumer emotions such as pleasure and arousal. Web cues, including background and text colour, animated logos and image interactivity play on mood and emotions as consumers browse (Eroglu et al., 2003; Fiore et al., 2005; Park et al., 2008; Wu et al., 2008; Young and Lennon, 2010). Some studies on human-computer interaction (HCI) (e.g. Koo and Ju, 2010; Sheng and Joginapelly 2012) evidence that website atmospherics, including graphics, colours and links, influence emotions. Etemad-Sajadi (2014) demonstrates that the aesthetic aspect of virtual agents impacts hedonic value, more specifically enjoyment. Therefore:

H6 Design linked to live chat services impacts emotions.

H6a Design linked to live chat services positively impacts positive emotions

Whenever the design quality of a product or service is poor and features fail to live up to customer needs, desires and expectations, customers may experience negative emotions (Meirovich and Bahnan, 2008). For example, Foroughi et al. (2019) demonstrate that poor peripheral services in a stadium, specifically facilities (e.g. seating comfort, stadium quality) and electronic devices (e.g. stadium lighting, screen size), contribute to a rise in unpleasant emotions in spectators. According to Wong (2004), a negative in-store experience reinforces negative emotional states, the assessment of the experience being based on elements of in-store atmosphere, such as lighting and layout or other. Transposing these findings to the context of virtual stores, we hypothesize as follows:

H6b Design linked to live chat services negatively impacts negative emotions.

\section{Methodology}

A self-administered Web questionnaire was distributed by a recognized Canadian research firm and answered by 682 panellists before the COVID-19 pandemic (autumn 2019). To be eligible to participate, respondents were required to be Canadian citizens over 18 years of age and must have used a 
financial institution's live chat services within the previous 12 months. Survey respondents were asked to think about their last use of their financial institution's live chat services. The sample comprised women in a proportion of $52.9 \%$ and men in a proportion of $47.1 \%$, with the median age situated between 35 and 44 years. More than 30\% of respondents had an undergraduate degree and reported median personal income before taxes of between $\$ 60,000$ and $\$ 79,999$.

To measure the constructs, different scales were used. Accessibility was evaluated using the Bressolles scale (2006) to test for ease of use. Two items were developed and added to better examine the concept in a live chat services context. The customer service and support construct was adapted from scales validated in the literature (Shankar and Jebarajakirthy, 2019; Srinivasan et al., 2002). Perceived security/privacy was measured using a scale by Chen and Barnes (2007) and design with a scale by Bressolles (2006). Emotions (positive-happy, amused and delighted, and negativefrustrated, angry, anxious and confused) were adapted from Ribeiro and Prayag (2018). Lastly, positive word of mouth was evaluated using the Yi and Gong scale (2013). All items are measured using a 7-point Likert scale.

To ensure data quality and detect inattentive or fraudulent respondents (Gao et al., 2016), validity or 'red herring' questions were included in the questionnaire (i.e. if you read this question, please answer 2), and respondents showing repetitive patterns in their answers were deleted from the final sample.

A confirmatory factor analysis (CFA) was conducted, and the theoretical framework was tested using structural equation modelling (EQS 6.2).

\section{Results}

\section{Reliability and validity}

Results show the reliability indices (alphas and composite reliability indices) to be very good (greater than 0.70 for all constructs). (Please see Table 2.)

Convergent validity was confirmed since all factor loadings were greater than or close to 0.70 (except for positive emotion - amused at 0.64) and average variance extracted (AVE) was greater than 0.50 (ranges from 0.60 (positive emotions) to 0.89 (word of mouth)) (Fornell and Larcker, 1981). Discriminant validity was also achieved since no squared correlation between each pair of constructs exceeded the AVE per construct indicator. (Please see Table 3.)

\section{Measurement model}

The measurement model fits the data extremely well. More specifically, the $\chi^{2}$ value is 706.73 with 329 degrees of

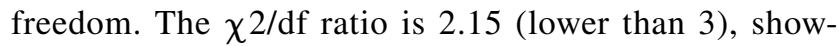
ing the model to be good. Model indicators are also good and exhibit excellent fit $(\mathrm{NNFI}=0.99 ; \mathrm{CFI}=0.99$; SRMR $=0.05 ;$ RMSEA $=0.05 ; 90 \%$ confidence interval of RMSEA $=0.043-0.053)$.

Since the survey technique involves self-declared data, there exists a risk of common method variance. Two procedures were carried out to address the issue. Firstly, a singlefactor Harman test was conducted (Podsakoff and Organ 1986). Test findings suggest the presence of five factors (not just one), indicating that the effects of the common method do not impact the findings observed in the study. Further, as recommended by Podsakoff et al. (2003), the multifactor measurement model was tested with an additional method factor. Overall, the model presents good indices (CFI at 0.98 and RMSEA at 0.05). All factor loadings remain significant and of similar amplitude which cannot therefore be explained by a systematic error associated with the method (Grégoire et al. 2010). The outcome of these tests suggests that common method variance is not a pervasive issue in this study.

\section{Structural model}

Figure 1 shows that $\mathrm{H} 1$ and $\mathrm{H} 2$ are each confirmed since $45.8 \%$ of the variance in positive word of mouth is explained by emotions, both positive and negative, the former exerting a slightly greater impact ( $\gamma=0.44$ vs -0.39 for negative emotions). Regarding live chat services in the banking sector, customer service and support proves the most important factor impacting positive emotions $(\gamma=0.52)$ and negative emotions $(\gamma=0.55)$. In the latter case, it alone accounts for $32.7 \%$ of the variance. Live chat service design influences only positive emotions $(\gamma=0.38)$ which together with customer service and support explain $38.7 \%$ of total variance. Interestingly, in this model neither accessibility nor perceived security/privacy emerges as influencing consumer emotions. Therefore, $\mathrm{H} 4$ (customer service and support) is confirmed but $\mathrm{H6}$ (design) only partially confirmed, while H3 (accessibility) and H5 (perceived security/privacy) must be rejected.

\section{Discussion}

The twofold purpose of this study was to investigate the impact of positive and negative emotions on customer positive word-of-mouth intentions respecting live chat services and to identify which dimensions of e-service quality impact the emotions experienced by banking customers when using live chat services.

Results reveal that the emotions, both positive and negative, experienced when using live chat services significantly 
Table 2 Results for the measurement model

\begin{tabular}{lc}
\hline Construct & Factor loadings Average vari- $\begin{array}{l}\text { Alphas/comp. rel } \\
\text { ance extracted } \\
\text { (rvc) }\end{array}$ \\
\hline
\end{tabular}

Positive emotions

$\mathbf{0 . 6 0}$

$0.82 / 0.82$

Recalling the emotions experienced during your last use of the live chat services of the financial institution, please indicate your level of agreement with each of the following emotions

Happy

Amused

0.64

Delighted

0.88

Negative emotions

0.64

$0.87 / 0.87$

Frustrated

0.89

Angry

0.88

Anxious

0.69

Confused

Positive Wom

$0.96 / 0.96$

I would say positive things about this live chat service to others

0.92

I would recommend this live chat service to others

I would encourage friends and relatives to use this live chat service

0.94

E-Service quality

Accessibility

$0.87 / 0.88$

It was easy to locate the live chat service on the financial institution's website or mobile application

The live chat service was easy to use

The live chat service was available when I needed it

The live chat service was appropriately adapted to the platform used (e.g. mobile telephone, tablet)

Customer service and support

0.86

The live chat service agent offered me personalized products and services based on my needs

The live chat service agent easily adapted to me

The live chat service agent's answers were personalized and based on my needs $\quad 0.83$

$\begin{array}{ll}\text { The live chat service agent was competent in his/her field } & 0.87\end{array}$

$\begin{array}{ll}\text { The live chat service agent kept his/her promises and commitments } & 0.88\end{array}$

$\begin{array}{ll}\text { The live chat service agent acted based on my interests } & 0.87\end{array}$

The live chat service agent answered my questions promptly 0.82

The live chat service agent adequately answered all my questions 0.86

Perceived security/privacy

$0.94 / 0.95$

I believe that anypersonal information provided during my last use of the live chat service 0.91 was well protected

I believe that the transactions carried out during my last use of the live chat service were secure

I believe that the confidentiality and privacy of my personal information were assured during my last use of the live chat service

Design

0.93

I found the design of the live chat service to be creative

I liked the design of the live chat service platform

impact positive word of mouth. These results are consistent with those appearing in the literature in other contexts such as when using social media, attending a music festival
(Hudson et al., 2015), viewing a film in a movie theatre (Ladhari, 2007) or evaluating a university (White, 2010). Accepting that word of mouth plays an important role in 
Table 3 Discriminant validity ${ }^{\mathrm{a}}$

\begin{tabular}{llllllll}
\hline CONSTRUCTS & $(1)$ & $(2)$ & $(3)$ & (4) & (5) & (6) & (7) \\
\hline Positive emotions (1) & $\mathbf{0 . 6 0}$ & & & & & & \\
Negative emotions (2) & 0.23 & $\mathbf{0 . 6 4}$ & & & & & \\
Positive WOM (3) & 0.30 & 0.30 & $\mathbf{0 . 8 9}$ & & & & \\
Accessibility (4) & 0.13 & 0.16 & 0.39 & $\mathbf{0 . 6 5}$ & & & \\
Customer service and support (5) & 0.26 & 0.29 & 0.56 & 0.61 & $\mathbf{0 . 6 9}$ & & \\
Perceived security/privacy (6) & 0.16 & 0.19 & 0.46 & 0.44 & 0.64 & $\mathbf{0 . 8 7}$ & \\
Design(7) & 0.27 & 0.18 & 0.49 & 0.41 & 0.53 & 0.48 & $\mathbf{0 . 7 8}$ \\
\hline
\end{tabular}

Average variance extracted (AVE) on-diagonal and squared correlations among constructs off-diagonal

Fig. 1 Structural model results

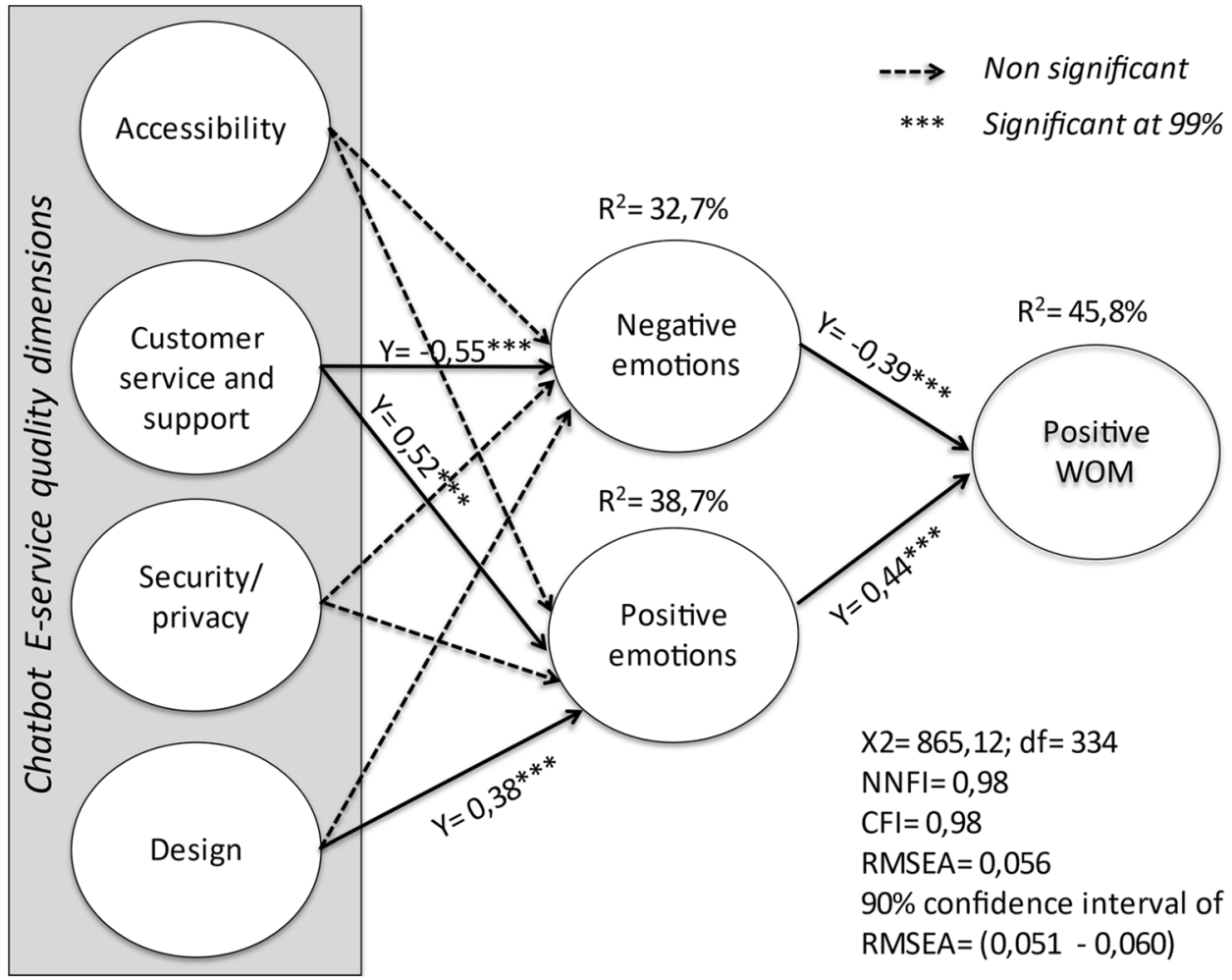

technology adoption (Tsai and Compeau, 2010), study findings substantiate the importance of prioritizing emotions in the case of live chat services, especially given the ever increasing popularity of these services as detailed earlier.

Consideration of the valence of emotions is also apropos since consumer reactions to technology can spawn both positive and negative emotions (Parasuraman et al., 2005). Whereas some studies point to the predominance of negative emotions in the context of discussion forums (Haavisto and Sandberg, 2015), this study, despite demonstrating the influence of both categories of emotions, finds positive emotions to exert a greater impact ( $\gamma=0.44$ vs -0.39). Individuals amused by or happy and delighted with live chat services are more likely to recommend and say positive things about these services to others, or encourage friends and relatives to use them. This result is interesting because in the context of the study, the mean of positive emotions was relatively low (3.78/7), leaving room for improvement.

Regarding the dimensions of e-service quality, results show that accessibility and perceived security/privacy do not affect emotions, either positive or negative. One plausible explanation is that customers might consider these two dimensions of e-service quality as prerequisites during chat sessions. In fact, in terms of security, approximately three out of four Internet users trust the websites of financial institutions more than other transactional websites (Centre facilitant la recherche et l'innovation dans les organisations [CEFRIO], 2019). Moreover, in this study, these two dimensions exhibit the highest means (accessibility 5.81/7, security/privacy 5.59/7 compared with customer service and support 5.49/7 and design 4.93/7). One might therefore tend 
to postulate that differentiation takes place with the aid of the other two dimensions.

Customer service and support together with design are nonetheless the dimensions which stand out in the model. The live chat service agent plays an important role given that customer service and support impact emotions both positive and negative, as Ribeiro and Prayag (2018) evidence in their study of restaurant service experience. Indeed, as individuals rely more and more on technology, they favour seeking out needed information themselves. The role of the agent has therefore evolved over time (Evanschitzky et al., 2012). Customers are increasingly demanding of service personnel, if and when they decide to engage with the latter (Beatty et al., 2016). Chat services therefore represent a support tool perfectly suited to new customer needs and behaviours.

This study substantiates that design engenders positive emotions. Several authors (e.g. Koo and Ju, 2010; Sheng and Joginapelly 2012) have previously demonstrated that the ambience created by site design has the power to generate positive emotions. Consistent with environmental psychology theory (Mehrabian and Russel 1974), the study by Uhrich and Benkenstein (2012) demonstrates that a favourable perception of 'design cues' positively influences emotional responses of customers. Moreover, of all the environmental factors (i.e. ambience, design and social factors), design is the dimension that exercises the most powerful impact on affective responses. In the same study, these affective responses are in turn shown to positively relate to positive word of mouth. In the case of live chat services, this dimension clearly fosters positive emotions such as delight, pleasure and fun even though the banking sector is generally characterized as more utilitarian in nature.

This research presents some key theoretical implications. First, findings complement the few studies (e.g. Hudson et al., 2015; Ladhari, 2007; White, 2010) having examined the impact of various emotions (positive and negative) on WOM. Moreover, to our knowledge, this paper is the first to respond to the research pathway extended by Ismagilova et al. (2020) who suggest that these links be examined in an online context. This study indeed fills the gap by considering the use of live chat services.

Moreover, this study ranks among the few (e.g. Herington and Weaven, 2007) that examine emotions in a utilitarian context such as banking. Interestingly, even though some authors (e.g. Herington and Weaven, 2007; Loureiro and Roschk, 2014) state that emotions are of little relevance in such a context, our findings demonstrate that they are indeed important since both types of emotions impact WOM and explain a good variance of the latter (over $45 \%$ ).

Lastly, online banking studies have, to date, investigated the impact of service quality on relationships (trust, Ladhari and Leclerc, 2013; Shankar and Jebarajakirthy, 2019; satisfaction, Ladhari and Leclerc, 2013; Raza et al., 2020) and loyalty/WOM (Amin, 2016; Shankar and Jebarajakirthy, 2019). Our research adds to this theoretical body of work with its first-time focus on live chat service quality as opposed to banking website service quality in general.

The results of this study have important practical implications. Chat services provide added value by fulfilling trending customer needs for personalized help whenever they need it. To integrate this type of service successfully, one must optimize the dimensions of the chat service that are likely to convey positive emotions, in particular and as shown in this research, support function and design.

Firstly, regarding support function, the front-office employees shape a large part of the service offer. Chat agents must therefore be able to respond adequately to questions, complaints or problems and have the necessary skill set to do so, hence the importance of recruiting and training highquality online customer service agents. To resolve problems or concerns effectively and quickly, it is equally important to give these agents sufficient leeway and decision-making accountability (employee empowerment) as well as access to abundant customer data. For example, HelpCrunch, a deeply integrated customer communication platform, offers corporate clients live chat software that provides detailed real-time data respecting visitor profiles, geographic locations and website-based actions. Lastly, in addition to having the 'know-how' and 'hard skills' (technical abilities), agents must also possess 'soft skills' (interpersonal or people skills). They must exhibit the human qualities or character traits such as politeness, benevolence, empathy, attention and courtesy. Agents must also learn how to detect negative user emotions (e.g. expression of anger, disappointment) and turn the situation around to promote positive word of mouth. In short, customers must sense that the service agents understand their needs, that they will do everything possible to meet these needs adequately, and that they are honest and dependable.

Secondly, good support service should be combined with the development of a creative, attractively designed chat window in keeping with target customer needs and tastes. For example, professional photographs of agents can be inserted to lend a human, aesthetically pleasing touch to websites. Chat buttons and windows created in keeping with website style and design also help deliver consistency while enhancing the overall browser experience. The Live Chat Company (a live chat application solution for businesses) for example allows users to define the theme, colours and position of the chat window. All things considered, the chat window must be functional, ergonomic, user-friendly, aesthetic and, at its finest, customizable. To achieve this, businesses must be able to intervene on various virtual atmospheric cues (e.g. text font, background, logo, emoticon, image, aesthetic representation of the agent, animation, colour, chat button/window graphics, speed of execution). 


\section{Conclusion}

The findings herein complement those of other researchers (e.g. Koo and Ju, 2010; Rose et al., 2012; Sheng and Joginapelly, 2012; Young and Lennon 2010) who examine the impact of certain characteristics on emotions experienced online. This study is, however, the first to investigate these characteristics in a live chat services context and presents the advantage of considering the two valences of emotions. Moreover, the work at hand substantiates the importance of emotions given that the latter impact word of mouth in the relatively recent context of live chat services.

This study enriches the theoretical body of knowledge relating to live chat services and online emotions. It contributes in important ways to the e-service literature as live chat services constitute a hybrid form of e-service that combines offline with online. The topic will gain importance as live chat services gain in prominence, especially after the COVID-19 pandemic. Indeed, the pandemic has considerably disrupted many sectors of commercial endeavour (Donthu and Gustafsson, 2020). This crisis has also prompted consumers to adopt new technologies and applications out of necessity (Sheth, 2020), paving the way for added research in the field.

The study is not, however, devoid of certain limitations. Although this research examines the impact of emotions on positive word of mouth, others might wish to consider the addition of the impact on negative word of mouth (Goyette et al., 2010) or no word of mouth at all. A future study based on experimentation could also be undertaken. For example, the two important constructs in this study (customer service and support and design) could be manipulated to examine their impact on customer emotions. The latter could also be evaluated using implicit measures (i.e. analysis of facial expressions via the FaceReader software). Also, while some studies (e.g. Hill et al. 2015) examine differences between live chat services (human-to-human communications) and chatbot services (computer-mediated communications), to our knowledge, none have to date explored whether or not there exist differences in the emotions experienced in each of these contexts. Recent research has even shown that the humanness of online agents or avatars may affect consumer behaviour (Ng et al., 2020; Wiese and Weis 2020), opening the door to more in-depth investigations regarding affect in this field.

\section{References}

Alhidari, A., P. Iyer, and A. Paswan. 2015. Personal level antecedents of eWOM and purchase intention, on social networking sites.
Journal of Customer Behaviour 14 (2): 107-125. https://doi. org/10.1362/147539215X14373846805707.

Al-Nasser, M., R. Zien Yusoff, R. Islam, and ALNasser, A. . 2013. E-service quality and its effect on consumers' perceptions trust. American Journal of Economics and Business Administration 5 (2): 47-55. https://doi.org/10.3844/ajebasp.2013.47.55.

Al-Sharafi, A.M., R.A. Arshah, A.T. Herzallah, and F. and AbuShanab, E. A. . 2018. The impact of customer trust and perception of security and privacy on the acceptance of online banking services: Structural equation modeling approach. International Journal of Industrial Management 4: 1-14.

Amin, M. 2016. Internet banking service quality and its implication on e-customer satisfaction and e-customer loyalty. International Journal of Bank Marketing 34 (3): 280-306. https:// doi.org/10.1108/IJBM-10-2014-0139.

Bagozzi, R.P., M. Gopinath, and P.U. Nyer. 1999. The role of emotions in marketing. Journal of the Academy of Marketing Science 27 (2): 184-206. https://doi.org/10.1177/0092070399 272005.

Baker, J., A. Parasuraman, D. Grewal, and G.B. Voss. 2002. The influence of multiple store environment cues on perceived merchandise value and patronage intentions. Journal of Marketing 66 (2): 120-141. https://doi.org/10.1509/jmkg.66.2.120.18470.

Balaji, M.S., S.K. Roy, and A. Quazi. 2017. Customers' emotion regulation strategies in service failure encounters. European Journal of Marketing 51 (5/6): 960-982. https://doi.org/10.1108/ EJM-03-2015-0169.

Barnes, S.J., and R.T. Vidgen. 2003. An integrative approach to the assessment of e- commerce quality. Journal of Electronic Commerce Research 3 (3): 114-127.

Bauer, H.H., T. Falk, and M. Hammerschmidt. 2006. eTransQual: A transaction process-based approach for capturing service quality in online shopping. Journal of Business Research 59 (7): 866875. https://doi.org/10.1016/j.jbusres.2006.01.021.

Beatty, S.E., J. Ogilvie, W.M. Northington, M.P. Harrison, B.B. Holloway, and S. Wang. 2016. Frontline service employee compliance with customer special requests. Journal of Service Research 19 (2): 158-173. https://doi.org/10.1177/1094670515624978.

Bitner, M.J. 1992. Servicescapes: The impact of physical surroundings on customers and employees. Journal of Marketing 56 (2): 57-71. https://doi.org/10.2307/1252042.

Blut, M. 2016. E-service quality: Development of a hierarchical model. Journal of Retailing 92 (4): 500-517. https://doi.org/10.1016/j. jretai.2016.09.002.

Blut, M., N. Chowdhry, V. Mittal, and C. Brock. 2015. E-service quality: A meta-analytic review. Journal of Retailing 91 (4): 679700. https://doi.org/10.1016/j.jretai.2015.05.004.

Boateng, S.L., and B. Narteh. 2016. Online relationship marketing and affective customer commitment-The mediating role of trust. Journal of Financial Services Marketing 21 (2): 127-140. https:// doi.org/10.1057/fsm.2016.5.

Bressolles, G. 2006. La qualité de service électronique : NetQu@1 Proposition d'une échelle de mesure appliquée aux sites marchands et effets modérateurs. Recherche Et Applications En Marketing 21 (3): 19-46. https://doi.org/10.1177/076737010602100 302.

Bressolles, G., and J. Nantel. 2008. The measurement of e-service quality: Improvements and applications. International Journal of e-Business Research 4 (3): 1-19. https://doi.org/10.4018/jebr. 2008070101.

Bui, M., and E. Kemp. 2013. E-tail emotion regulation: Examining online hedonic product purchases. International Journal of Retail \& Distribution Management 41 (2): 155-170. https://doi.org/10. 1108/09590551311304338.

Cai, S., and M. Jun. 2003. Internet users' perceptions of online service quality: A comparison of online buyers and information 
searchers. Managing Service Quality 13: 504-519. https://doi. org/10.1108/09604520310506568.

Carlos Roca, J., J. José García, and J. José de la Vega. 2009. The importance of perceived trust, security and privacy in online trading systems. Information Management \& Computer Security 17 (2): 96-113. https://doi.org/10.1108/09685220910963983.

Casaló Ariño, L., C. Flavian, and M. Guinalìu. 2008. The role of satisfaction and website usability in developing customer loyalty and positive word-of-mouth in the e-banking services. International Journal of Bank Marketing 26 (6): 399-417. https://doi.org/10. 1108/02652320810902433.

Centre facilitant la recherche et l'innovation dans les organisations [CEFRIO]. (2019) NETendances 2019 - Services bancaires en ligne, NETandances 2019, 10(3), https://transformation-numer ique.ulaval.ca/wp-content/uploads/2020/09/netendances-2019services-bancaires-en-ligne.pdf, Accessed 29 September 2020.

Chattaraman, V., W.-S. Kwon, and J.E. Gilbert. 2012. Virtual agents in retail web sites: Benefits of simulated social interaction for older users. Computers in Human Behavior 28 (6): 2055-2066. https:// doi.org/10.1016/j.chb.2012.06.009.

Chen, Y.-H., and S. Barnes. 2007. Initial trust and online buyer behavior. Industrial Management \& Data Systems 107 (1): 21-36. https://doi.org/10.1108/02635570710719034.

Chen, N.C., L. Dwyer, and T. Firth. 2014. Effect of dimensions of place attachment on residents' word-of-mouth behavior. Tourism Geographies 16 (5): 826-843. https://doi.org/10.1080/14616688. 2014.915877.

Chen, C.-H., W.P. Lee, and J.-Y. Huang. 2018. Tracking and recognizing emotions in short text messages from online chatting services. Information Processing \& Management 54 (6): 13251344. https://doi.org/10.1016/j.ipm.2018.05.008.

Chen, A., N. Peng, and K.P. Hung. 2015. The effects of luxury restaurant environments on diners' emotions and loyalty: Incorporating diner expectations into an extended Mehrabian-Russell model. International Journal of Contemporary Hospitality Management 27 (2): 236-260. https://doi.org/10.1108/IJCHM-07-2013-0280.

Chiu, H.-C., and H.-C. Wu. 2002. Exploring the cognitive and affective roles of Service quality attitude across gender. The Service Industries Journal 22 (3): 63-76. https://doi.org/10.1080/714005093.

Chung, M., E. Ko, H. Joung, and S.J. Kim. 2020. Chatbot e-service and customer satisfaction regarding luxury brands. Journal of Business Research 117: 587-595. https://doi.org/10.1016/j.jbusr es.2018.10.004.

Chung, K., and J.-I. Shin. 2010. The antecedents and consequents of relationship quality in Internet shopping. Asia Pacific Journal of Marketing and Logistics 22 (4): 473-491. https://doi.org/10. 1108/13555851011090510.

Cohen-Charash, Y., and P.E. Spector. 2001. The role of justice in organizations: A meta- analysis. Organizational Behavior and Human Decision Processes 86 (2): 278-321. https://doi.org/10. 1006/obhd.2001.2958.

Collier, J., and C. Bienstock. 2006. Measuring service quality in e-retailing. Journal of Service Research 8 (3): 260-275. https:// doi.org/10.1177/1094670505278867.

Dai, H., P. Haried, and A.F. Salam. 2011. Antecedents of online service quality, commitment and loyalty. The Journal of Computer Information Systems 52 (2): 1-11. https://doi.org/10.1080/08874 417.2011.11645535.

Damghanian, H., A. Zarei, and M.A. Siahsarani Kojuri. 2016. Impact of perceived security on trust, perceived risk, and acceptance of online banking in Iran. Journal of Internet Commerce 15 (3): 214-238. https://doi.org/10.1080/15332861.2016.1191052.

Das, G., and G. Varshneya. 2017. Consumer emotions: Determinants and outcomes in a shopping mall. Journal of Retailing and Consumer Services 38: 177-185. https://doi.org/10.1016/j.jretconser. 2017.06.008.
Dellarocas, C., X. Zhang, and N. Awad. 2007. Exploring the value of online product reviews in forecasting sales. Journal of Interactive Marketing 21 (4): 23-45. https://doi.org/10.1002/ dir.20087.

Donovan, R.J., and J.R. Rossiter. 1982. Store atmosphere: An environmental psychology approach. Journal of Retailing 58 (1): 34-57.

Donthu, N., and A. Gustafsson. 2020. Effects of COVID-19 on business and research. Journal of Business Research. 117: 284-289. https://doi.org/10.1016/j.jbusres.2020.06.008.

Dubé-Rioux, L. 1990. The power of affective reports in predicting satisfaction judgments. Advances in Consumer Research 17: 571-576.

Elmorshidy, A. 2013. Applying the technology acceptance and the service quality models to live customer support chat fort e-commerce Websites. The Journal of Applied Business Research 29 (2): 589-595. https://doi.org/10.19030/jabr.v29i2.7659.

Elmorshidy, A., M. Mostafa, I. El-Moughrabi, and H. Al-Mezen. 2015. Factors influencing live customer support chat services: An empirical investigation in Kuwait. Journal of Theoretical and Applied Electronic Commerce Research 10 (3): 63-76. https:// doi.org/10.4067/S0718-18762015000300006.

eMarketer. 2019a. Which channels do US Customers prefer when communicating with companies?, April 2019, https://chart-na1. emarketer.com/229209/which-channels-do-us-customers-prefercommunicating-with-companies-of-respondents-by-generationapril-2019, Accessed 4 April 2020.

eMarketer. 2019b. How Do Internet Users in Europe and North America Prefer to Contact Customer Service?, July 2019, https:// chart-na1.emarketer.com/231111/how-do-internet-users-europenorth-america-prefer-contact-customer-service-of-respondentsjuly-2019, Accessed 4 April 2020.

Erevelles, S. 1998. The role of affect in marketing. Journal of Business Research 42 (3): 199-215. https://doi.org/10.1016/S01482963(97)00118-5.

Eroglu, S.A., K.A. Machleit, and L.M. Davis. 2003. Empirical testing of a model of online store atmospherics and shopper responses. Psychology \& Marketing 20 (2): 139-150. https://doi.org/10. 1002/mar.10064.

Etemad-Sajadi, R. 2014. The influence of a virtual agent on web-users' desire to visit the company: The case of restaurant's web site. International Journal of Quality \& Reliability Management 31 (4): 419-434. https://doi.org/10.1108/IJQRM-05-2013-0077.

Éthier, J., P. Hadaya, J. Talbot, and J. Cadieux. 2008. Interface design and emotions felt on B2C Web sites: Empirical testing of a research model. Computers in Human Behavior 24 (6): $2771-$ 2791. https://doi.org/10.1016/j.chb.2008.04.004.

Evanschitzky, H., A. Sharma, and C. Prykop. 2012. The role of the sales employee in securing customer satisfaction. European Journal of Marketing 46 (3/4): 489-508. https://doi.org/10.1108/ 03090561211202576.

Fiore, A.M., H. Jin, and J. Kim. 2005. For fun and profit: Hedonic value from image interactivity and responses toward an online store. Psychology \& Marketing 22 (8): 669-694. https://doi.org/ 10.1002/mar.20079.

Fernandes, T., and J. Proença. 2013. Reassessing relationships in consumer markets : Emotion, cognition, and consumer relationship intention. Journal of Relationship Marketing 12 (1): 41-58. https://doi.org/10.1080/15332667.2013.763719.

Flavián, C., and M. Guinalíu. 2006. Consumer trust, perceived security and privacy policy: Three basic elements of loyalty to a web site. Industrial Management \& Data Systems 106 (5): 601-620. https://doi.org/10.1108/02635570610666403.

Fornell, C., and D.F. Larcker. 1981. Evaluating structural equation models with unobservable variables and measurement error. Journal of Marketing Research 18 (1): 39-50. https://doi.org/ $10.2307 / 3151312$ 
Foroughi, B., K.A. Shah, T. Ramayah, and M. Iranmanesh. 2019. The effects of peripheral service quality on spectators' emotions and behavioural intentions. International Journal of Sports Marketing and Sponsorship 20 (3): 495-515. https://doi.org/ 10.1108/IJSMS-08-2018-0082.

Gao, Z., L.A. House, and J. Xie. 2016. Online survey data quality and its implication for willingness-to-pay: A cross-country comparison. Canadian Journal of Agricultural Economics/ revue Canadienne D'agroéconomie 64 (2): 199-221. https:// doi.org/10.1111/cjag.12069.

Gaur, S., H. Herjanto, and M. Makkar. 2014. Review of emotions research in marketing, 2002-2013. Journal of Retailing and Consumer Services 21 (6): 917-923. https://doi.org/10.1016/j. jretconser.2014.08.009.

Gemar, G., I.P. Soler, and L. Melendez. 2019. Analysis of the intent to purchase travel on the web. Tourism Management Studies 15 (1): 23-33. https://doi.org/10.18089/tms.2019.150102.

Giraud, S., P. Thérouanne, and D. Steiner. 2018. Web accessibility: Filtering redundant and irrelevant information improves website usability for blind users. International Journal of HumanComputer Studies 111: 23-35. https://doi.org/10.1016/j.ijhcs. 2017.10.011.

Goodwin, C. 1991. Privacy: Recognition of a consumer right. Journal of Public Policy Marketing 10 (1): 149-166. https://doi. org/10.1177/074391569101000111.

Goutam, D., and B.V. Gopalakrishna. 2018. Customer loyalty development in online shopping: An integration of e-service quality model and commitment-trust theory. Management Science Letters 8: 1149-1158. https://doi.org/10.5267/j.msl.2018.8.009.

Goyette, I., L. Ricard, J. Bergeron, and F. Marticotte. 2010. E-WOM scale: Word-of-mouth measurement scale for e-services context. Canadian Journal of Administrative Sciences 27 (1): 5-23. https://doi.org/10.1002/cjas.129.

Grégoire, Y., D. Laufer, and T. Tripp. 2010. A comprehensive model of customer direct and indirect revenge: Understanding the effects of perceived greed and customer power. Journal of the Academy of Marketing Science 38: 738-758. https://doi.org/ 10.1007/s11747-009-0186-5.

Haavisto, P., and B. Sandberg. 2015. Man, this frustrates me: Change of consumer emotions in online discussions. Journal of Research in Interactive Marketing 9 (1): 70-87. https://doi. org/10.1108/JRIM-03-2014-0018.

Habib, M.D., and A. Qayyum. 2018. Cognitive emotion theory and emotion-action tendency in online impulsive buying behavior. Journal of Management Sciences 5 (1): 86-99.

Harris, L.C. 2013. Service employees and customer phone rage: An empirical analysis. European Journal of Marketing 47 (3): 463-484. https://doi.org/10.1108/03090561311297418.

Hart, J., and A. Sutcliffe. 2019. Is it all about the Apps or the Device?: User experience and technology acceptance among iPad users. International Journal of Human-Computer Studies 130: 93-112. https://doi.org/10.1016/j.ijhcs.2019.05.002.

Hemmasi, M., K.C. Strong, and S.A. Taylor. 1994. Measuring service quality for strategic planning and analysis in service firms. Journal of Applied Business Research 10 (4): 24. https://doi. org/10.19030/jabr.v10i4.5904.

Hennig-Thurau, T., K.P. Gwinner, G. Walsh, and D.D. Gremler. 2004. Electronic word-of-mouth via consumer-opinion platforms: What motivates consumers to articulate themselves on the Internet? Journal of Interactive Marketing 18 (1): 38-52. https://doi.org/10.1002/dir.10073.

Herington, C., and S. Weaven. 2007. Can banks improve customer relationships with high quality online services? Managing Service Quality: An International Journal 17 (4): 404-427. https://doi.org/10.1108/09604520710760544.
Hibbeln, M., J. Jenkins, C. Schneider, J. Valacich, and M. Weinmann. 2017. How is your user feeling? Inferring emotion through human-computer interaction devices. MIS Quarterly 41 (1): 1-21. https://doi.org/10.25300/MISQ/2017/41.1.01.

Hill, J., W.R. Ford, and I.G. Farreras. 2015. Real conversations with artificial intelligence: A comparison between human-human online conversations and human-chatbot. Computers in Human Behavior 49: 245-250. https://doi.org/10.1016/j.chb.2015.02. 026.

Holbrook, M.B., and E.C. Hirschman. 1982. Hedonic consumption: Emerging concepts methods and propositions. Journal of Marketing 46 (3): 92-10. https://doi.org/10.2307/1251707.

Huang, M.-H. 2001. The theory of emotions in marketing. Journal of Business and Psychology 16 (2): 239-247.

Hudson, S., M.S. Roth, T.J. Madden, and R. Hudson. 2015. The effects of social media on emotions, brand relationship quality, and word of mouth: An empirical study of music festival attendees. Tourism Management 47: 68-76. https://doi.org/10.1016/j.tourman. 2014.09.001.

Ismagilova, E., N.P. Rana, E.L. Slade, and Y.K. Dwivedi. 2020. A meta-analysis of the factors affecting eWOM providing behaviour. European Journal of Marketing 55 (4): 1067-1102. https:// doi.org/10.1108/EJM-07-2018-0472.

Iwaarden, J., T. Wiele, L. Ball, and R. Millen. 2003. Applying SERVQUAL to Web sites: An exploratory study. International Journal of Quality \& Reliability Management 20: 919-935. https://doi. org/10.1108/02656710310493634.

Izard, C.E. 1977. Human emotions. New York: Plenum Press.

Jahangir, N., and N. Begum. 2007. Effect of perceived usefulness, ease of use, security and privacy on customer attitude and adaptation in the context of E-banking. Journal of Management Research 7 (3): $147-157$.

Jang, S., and Y. Namkung. 2009. Perceived quality, emotions, and behavioral intentions: Application of an extended MehrabianRussell model to restaurants. Journal of Business Research 62 (4): 451-460.

Jokinen, J.P.P. 2015. Emotional user experience: Traits, events, and states. International Journal of Human-computer Studies 76: 67-77. https://doi.org/10.1016/j.ijhcs.2014.12.006.

Jun, M., Z. Yang, and D. Kim. 2004. Customers' perceptions of online retailing service quality and their satisfaction. International Journal of Quality \& Reliability Management 21 (8): 817-840. https://doi.org/10.1108/02656710410551728.

Kafetsios, K., D. Chatzakou, N. Tsigilis, and A. Vakali. 2017. Experience of emotion in face to face and computer-mediated social interactions: An event sampling study. Computers in Human Behavior 76: 287-293. https://doi.org/10.1016/j.chb.2017.07. 033.

Kalakota, R. and Whinston, A.B. 1996. Frontiers of Electronic Commerce. Pearson Education.

Kao, T-W. (Daniel) and Lin, W. 2016. The relationship between perceived e-service quality and brand equity: A simultaneous equations system approach. Computers in Human Behavior, 57, 208-218. https://doi.org/10.1016/j.chb.2015.12.006

Kasabov, E. 2016. Unknown, surprising, and economically significant: The realities of electronic word of mouth in Chinese social networking sites. Journal of Business Research 69 (2): 642-652. https://doi.org/10.1016/j.jbusres.2015.08.036.

Kim, J., and P. Gupta. 2012. Emotional expressions in online user reviews: How they influence consumers' product evaluations. Journal of Business Research 65: 985-992. https://doi.org/10. 1016/j.jbusres.2011.04.013.

Kim, J.-H., and M. Kim. 2020. Conceptualization and assessment of e-service quality for luxury brands. The Service Industries Journal 40 (5/6): 436-470. https://doi.org/10.1080/02642069.2018. 1517755 . 
Kim, J.-H., M. Kim, and J. Kandampully. 2007. The impact of buying environment characteristics of retail websites. The Service Industries Journal 27 (7): 865-880. https://doi.org/10.1080/ 02642060701570529.

Kim, J., and S.J. Lennon. 2013. Effects of reputation and website quality on online consumers' emotion, perceived risk and purchase intention. Journal of Research in Interactive Marketing 7 (1): 33-56. https://doi.org/10.1108/17505931311316734.

Koo, D.-M., and S.-H. Ju. 2010. The interactional effects of atmospherics and perceptual curiosity on emotions and online shopping intention. Computers in Human Behavior 26: 377-388. https:// doi.org/10.1016/j.chb.2009.11.009.

Ladhari, R. 2007. The effect of consumption emotions on satisfaction and word-of-mouth communications. Psychology \& Marketing 24 (12): 1085-1108. https://doi.org/10.1002/mar.20195.

Ladhari, R. 2010. A review of twenty years of SERVQUAL research. International Journal of Quality and Service Sciences 1 (2): 172-198. https://doi.org/10.1108/17566690910971445.

Ladhari, R., and A. Leclerc. 2013. Building loyalty with online financial services customers, is there a gender difference? Journal of Retailing and Consumer Services 20: 560-569. https://doi.org/ 10.1016/j.jretconser.2013.07.005.

Ladhari, R., N. Souiden, and B. Dufour. 2017. The role of emotions in utilitarian service settings: The effects of emotional satisfaction on product perception and behavioral intentions. Journal of Retailing and Consumer Services 34: 10-18. https://doi.org/10. 1016/j.jretconser.2016.09.005.

Laros, F.J.M., and J.-B.E.M. Steenkamp. 2005. Emotions in consumer behavior: A hierarchical approach. Journal of Business Research 58: 1437-1445. https://doi.org/10.1016/j.jbusres.2003.09.013.

Lee, K., J. Choi, G.M. Marakas, and S.N. Singh. 2019. Two distinct routes for inducing emotions in HCI design. International Journal of Human-Computer Studies 124: 6780. https://doi.org/10. 1016/j.ijhcs.2018.11.012.

Lee, S., L.B. Comer, A.J. Dubinsky, and K. Schafer. 2011. The role of emotion in the relationship between customers and automobile salespeople. Journal of Managerial Issues 23 (2): 206-226.

Lew, Z., J.B. Walther, A. Pang, and W. Shin. 2018. Interactivity in online chat : Conversational contingency and response latency in computer-mediated communication. Journal of ComputerMediated Communication 23 (4): 201-221. https://doi.org/10. 1093/jcmc/zmy009.

Liang, C.J., and H.-J. Chen. 2009. How to lengthen, deepen and broaden customer-firm relationships with online financial services. Journal of Financial Services Marketing 14 (3): 218-231. https://doi.org/10.1057/fsm.2009.20.

Liao, Z., and M.T. Cheung. 2008. Measuring consumer satisfaction in Internet banking: A core framework. Proceedings of the Association for Computing Machinery 51 (4): 47-51. https://doi.org/10. 1145/1330311.1330322.

Lien, C., Y. Coa, and X. Zhou. 2017. Service quality, satisfaction, stickiness, and usage intentions: An exploratory evaluation in the context of WeChat services. Computers in Human Behavior 68: 403-410. https://doi.org/10.1016/j.chb.2016.11.061.

Lin, J.C., and H. Liang. 2011. The influence of service environments on customer emotion and service outcomes. Managing Service Quality: An International Journal 21 (4): 350-372. https://doi. org/10.1108/09604521111146243.

Lin, J. 2013. Development of scales for the measurement of principles of design. International Journal of Human-Computer Studies 71 (12): 1112-1123. https://doi.org/10.1016/j.ijhcs.2013.08.003.

Lin, L., and C. Lu. 2010. The influence of corporate image, relationship marketing and trust on purchase intention: The moderating effects of word-of-mouth. Tourism Review 65 (3): 16-34. https:// doi.org/10.1108/16605371011083503.
Litvin, S., R. Goldsmith, and B. Pan. 2008. Electronic Word-of-Mouth in Hospitality and Tourism Management. Tourism Management 29: 458-468. https://doi.org/10.1016/j.tourman.2007.05.011.

Lo, A.S., and C. Wu. 2014. Effect of consumption emotion on hotel and resort spa experience. Journal of Travel \& Tourism Marketing 31 (8): 958-984. https://doi.org/10.1080/10548408.2014.895692.

Loureiro, S.M.C., and H. Roschk. 2014. Differential effects of atmospheric cues on emotions and loyalty intention with respect to age under online/offline environment. Journal of Retailing and Consumer Services 21 (2): 211-219. https://doi.org/10.1016/j. jretconser.2013.09.001.

Luo, M.M., J.-S. Chen, R.K.H. Ching, and C.-C. Liu. 2011. An examination of the effects of virtual experiential marketing on online customer intentions and loyalty. The Service Industries Journal 31 (13): 2163-2191. https://doi.org/10.1080/02642069.2010. 503885 .

Luonila, M., K. Suomi, and M. Johansson. 2016. Creating a stir: The role of word of mouth in reputation management in the context of festivals. Scandinavian Journal of Hospitality and Tourism 16 (4): 461-483. https://doi.org/10.1080/15022250.2015.1113646.

Magids, S., A. Zorfas, and D. Leemon. 2015. The new science of customer emotions : A better way to drive growth and profitability. Harvard Business Review 93 (11): 66-76.

Mangold, W.G., F. Miller, and G.R. Brockway. 1999. Word-of-mouth communication in the service marketplace. The Journal of Services Marketing 13 (1): 73-89. https://doi.org/10.1108/08876 049910256186.

Martin, W.C., and J.E. Lueg. 2013. Modeling word-of-mouth usage. Journal of Business Research 61 (7): 801-808. https://doi.org/ 10.1016/j.jbusres.2011.06.004.

Martins, J., R. Gonçalves, and F. Branco. 2017. A full scope web accessibility evaluation procedure proposal based on Iberian eHealth accessibility compliance. Computers in Human Behavior 73: 676-684. https://doi.org/10.1016/j.chb.2016.12.010.

Mattila, A.S., and C.A. Enz. 2002. The role of emotions in service encounters. Journal of Service Research 4 (4): 268-277. https:// doi.org/10.1177/1094670502004004004.

McCole, P., E. Ramsey, and J. Williams. 2010. Trust considerations on attitudes towards online purchasing: The moderating effect of privacy and security concerns. Journal of Business Research 63 (9/10): 1018-1024. https://doi.org/10.1016/j.jbusres.2009. 02.025 .

McLean, G.J. 2017. Investigating the online customer experience a B2B perspective. Marketing Intelligence \& Planning 35 (5): 657-672. https://doi.org/10.1108/MIP-12-2016-0222.

McLean, G., and K. Osei-Frimpong. 2017. Examining satisfaction with the experience during a live chat service encounter-implications for website providers. Computers in Human Behavior 76: 494-508. https://doi.org/10.1016/j.chb.2017.08.005.

McLean, G., and K. Osei-Frimpong. 2019. Chat now... Examining the variables influencing the use of online live chat. Technological Forecasting and Social Change 146: 55-67. https://doi.org/10. 1016/j.techfore.2019.05.017.

Meirovich, G., and N. Bahnan. 2008. Relationship between the components of product/service quality and the customers' emotions and satisfaction. Journal of Industrial Engineering and Management 1 (2): 186-208. https://doi.org/10.3926/jiem.v1n2.p186-208.

Mehrabian, A., and J.A. Russel. 1974. An approach to environmental psychology. MIT Press.

Mero, J. 2018. The effects of two-way communication and chat service usage on consumer attitudes in the e-commerce retailing sector. Electronic Markets 28 (2): 205-217. https://doi.org/10.1007/ s12525-017-0281-2.

Mehta, B. 2020. Self-service banking grows more important in a postpandemic world, 10 November 2020, https://thefinancialbrand. 
com/104081/self-service-banking-covid-19-pandemic-coron avirus, Accessed January 2021.

Moin, S.M.A., J.F. Devil, and S. Mckechnie. 2015. Trust in financial services: Impact of institutional trust and dispositional trust on trusting belief. Journal of Financial Services Marketing 20 (2): 91-106. https://doi.org/10.1057/fsm.2015.6.

Moore, R.S., C.A. Stammerjohan, and R.A. Coulter. 2005. Banner advertiser-web site context congruity and color effects on attention and attitudes. Journal of Advertising 34 (2): 71-84. https:// doi.org/10.1080/00913367.2005.10639189.

Murray, K.B. 1991. A test of services marketing theory: Consumer information acquisition activities. Journal of Marketing 55 (1): 10-25. https://doi.org/10.2307/1252200.

Ng, M., Coopamootoo, K.P.L., Toreini, E., Aitken, M., Elliot, K. and van Moorsel, A. 2020. Simulating the effects of social presence on trust, privacy concerns \& usage intentions in automated bots for finance. 2020 IEEE European Symposium on Security and Privacy Workshops (EuroS\&PW), 190-199. http://arxiv.org/abs/ 2006.15449

Oliver, R.L. 1993. Cognitive, affective and attribute bases of the satisfaction response. Journal of Consumer Research 20 (3): 418430. https://doi.org/10.1086/209358.

Ou, Y.-C., and P.C. Verhoef. 2017. The impact of positive and negative emotions on loyalty intentions and their interactions with customer equity drivers. Journal of Business Research 80: 106-115. https://doi.org/10.1016/j.jbusres.2017.07.011.

Ozen, H., and N. Engizek. 2014. Shopping online without thinking: Being emotional or rational? Asia Pacific Journal of Marketing and Logistics 26 (1): 78-93. https://doi.org/10.1108/ APJML-06-2013-0066.

Packard, G., and J. Berger. 2017. How language shapes word of mouth's impact. Journal of Marketing Research 54 (4): 572-588. https://doi.org/10.1509/jmr.15.0248.

Packard, G., A.D. Gershoff, and D.B. Wooten. 2016. When boastful word of mouth helps versus hurts social perceptions and persuasion. Journal of Consumer Research 43 (1): 26-43. https://doi. org/10.1093/jcr/ucw009.

Parasuraman, A., L.L. Berry, and V.A. Zeithaml. 1991. Perceived service quality as a customer-based performance measure: An empirical examination of organizational barriers using an extended service quality model. Human Resource Management 30 (3): 335-364. https://doi.org/10.1002/hrm.3930300304.

Parasuraman, A., V.A. Zeithaml, and A. Malhotra. 2005. E-S-QUAL: A multiple-item scale for assessing electronic service quality. Journal of Service Research 7 (3): 213-233. https://doi.org/10. 1177/1094670504271156.

Park, J.H., L. Stoel, and S.J. Lennon. 2008. Cognitive, affective, and conative responses to visual simulation: The effects of rotation in online product presentation. Journal of Consumer Behaviour 7 (1): 72-87. https://doi.org/10.1002/cb.237.

Peng, N., A. Chen, and K.P. Hung. 2017. The effects of teppanyaki restaurant stimuli on diners' emotions and loyalty. International Journal of Hospitality Management 60: 1-12. https://doi.org/10. 1016/j.ijhm.2016.09.010.

Phillips, D.M., and H. Baumgartner. 2002. The role of consumption emotions in the satisfaction response. Journal of Consumer Psychology 12 (3): 243-252. https://doi.org/10.1207/S15327663J CP1203_06.

Piercy, N. 2014. Online service quality: Content and process of analysis. Journal of Marketing Management 30 (7/8): 747-785. https://doi.org/10.1080/0267257X.2013.839571.

Plutchik, R. 1980. Emotion: A psycho-evolutionary synthesis. New York: Harper \& Row.

Podsakoff, P.M., S.B. Mackenzie, and J.-Y. Lee. 2003. Common method biases in behavioral research: A critical review of the literature and recommended remedies. Journal of Applied Psychology 88 (5): 879-903. https://doi.org/10.1037/0021-9010.88.5.879.

Podsakoff, P.M., and D.W. Organ. 1986. Self-reports in organizational research: Problems and prospects. Journal of Management 12 (4): 69-82. https://doi.org/10.1177/014920638601200408.

Raza, S.A., A. Umer, M.A. Qureshi, and A.S. Dahri. 2020. Internet banking service quality, e-customer satisfaction and loyalty: The modified e-servqual model. TQM Journal 32 (6): 1443-1466. https://doi.org/10.1108/TQM-02-2020-0019.

Ribeiro, M.A., and G. Prayag. 2018. Perceived quality and service experience: Mediating effects of positive and negative emotions. Journal of Hospitality Marketing \& Management 28 (3): 285305. https://doi.org/10.1080/19368623.2018.1517071.

Richins, M. 1997. Measuring emotions in the consumption experience. Journal of Consumer Research 24 (2): 127-146. https://doi.org/ 10.1086/209499.

Rodríguez, G., J. Pérez, S. Cueva, and R. Torres. 2017. A framework for improving web accessibility and usability of Open Course Ware sites. Computers \& Education 109: 197-215. https://doi. org/10.1016/j.compedu.2017.02.013.

Rose, S., M. Clark, P. Samouel, and N. Hair. 2012. Online customer experience in e-retailing: An empirical model of antecedents and outcomes. Journal of Retailing 88 (2): 308-322. https://doi.org/ 10.1016/j.jretai.2012.03.001.

Roseman, I. 1991. Appraisal determinants of discrete emotions. Cognition and Emotion 5 (3): 161-200. https://doi.org/10.1080/02699 939108411034.

Rousi, R., and R. Renko. 2020. Emotions toward cognitive enhancement technologies and the body-Attitudes and willingness to use. International Journal of Human-Computer Studies 143: 102472. https://doi.org/10.1016/j.ijhcs.2020.102472.

Rychalski, A., and S. Hudson. 2017. Asymmetric effects of customer emotions on satisfaction and loyalty in a utilitarian service context. Journal of Business Research 71: 84-91. https://doi.org/10. 1016/j.jbusres.2016.10.014.

Santos, J. 2003. E-service quality: A model of virtual service quality dimensions. Managing Service Quality: An International Journal 13 (3): 233-246. https://doi.org/10.1108/0960452031 0476490.

Schnebelen, S., and M. Bruhn. 2018. An appraisal framework of the determinants and consequences of brand happiness. Psychology \& Marketing 35 (2): 101-119. https://doi.org/10.1002/mar. 21073.

Shafiee, M.M., and N.A. Bazargan. 2018. Behavioral customer loyalty in online shopping: The role of E-service quality and E-recovery. Journal of Theoretical and Applied Electronic Commerce Research 13 (1): 26-38.

Shank, D.B. 2014. Impressions of computer and human agents after interaction: Computer identity weakens power but not goodness impressions. International Journal of Human-Computer Studies 72 (10): 747-756. https://doi.org/10.1016/j.ijhcs.2014.05.002.

Shankar, A., and C. Jebarajakirthy. 2019. The influence of e-banking service quality on customer loyalty: A moderated mediation approach. International Journal of Bank Marketing 37 (5): 1119-1142. https://doi.org/10.1108/IJBM-03-2018-0063.

Sharma, G., and W. Lijuan. 2015. The effect of online service quality of e-commerce websites on user satisfaction. The Electronic Library 33 (3): 468-485. https://doi.org/10.1108/EL-10-2013-0193.

Sheng, H., and T. Joginapelly. 2012. Effects of Web atmospheric cues on users' emotional responses in e-commerce. AIS Transactions on Human-Computer Interaction 4 (1): 1-24. https://doi.org/10. 1108/EL-10-2013-0193.

Sherman, E., A. Mathur, and R.B. Smith. 1997. Store environment and consumer purchase behavior: Mediating role of consumer emotions. Psychology \& Marketing 14 (4): 361-378. https://doi.org/ 
10.1002/(SICI)1520-6793(199707)14:4\%3c361::AID-MAR4\% 3e3.0.CO;2-7.

Sheth, J. 2020. Impact of Covid-19 on consumer behavior: Will the old habits return or die? Journal of Business Research 117: 280-283. https://doi.org/10.1016/j.jbusres.2020.05.059.

Srinivasan, S.S., R. Anderson, and K. Ponnavolu. 2002. Customer loyalty in e-commerce: An exploration of its antecedents and consequences. Journal of Retailing 78 (1): 41-50. https://doi. org/10.1016/S0022-4359(01)00065-3.

Steffes, E.M., and L.E. Burgee. 2009. Social ties and online word of mouth. Internet Research 19 (1): 42-59. https://doi.org/10.1108/ 10662240910927812.

Stremtan, F., and A. Muntean. 2008. Measuring quality of the services provided by the commercial web sites. Annales Universitatis Apulensis Series Oeconomica 2 (10): 53-56.

Sweeney, J.C., G.N. Soutar, and T. Mazzarol. 2012. Word of mouth: Measuring the power of individual messages. European Journal of Marketing 46 (1/2): 237-257. https://doi.org/10.1108/03090 561211189310.

Trocchia, P., and S. Janda. 2003. How do consumers evaluate Internet retail service quality? Journal of Services Marketing 17 (3): 243-253. https://doi.org/10.1108/08876040310474800.

Trusov, M., R.E. Bucklin, and K. Pauwels. 2009. Effects of word-ofmouth versus traditional marketing: Findings from an Internet social networking site. Journal of Marketing 73 (5): 90-102. https://doi.org/10.1509/jmkg.73.5.90.

Tsai, P. and Compeau, D. 2010. Go tell it on the mountains: How word of mouth can lead to buy-in of a technology. Ivey Business Journal, online publication March/Avril, https://iveybusinessjou rnal.com/publication/go-tell-it-on-the-mountains-how-word-ofmouth-can-lead-to-buy-in-of-a-technology-2/

Turel, O., and C.E. Connelly. 2013. Too busy to help: Antecedents and outcomes of interactional justice in web-based service encounters. International Journal of Information Management 33 (4): 674-683. https://doi.org/10.1016/j.ijinfomgt.2013.03.005.

Uhrich, S., and M. Benkenstein. 2012. Physical and social atmospheric effects in hedonic service consumption: Customers' roles at sporting events. The Service Industries Journal 32 (11): 17411757. https://doi.org/10.1080/02642069.2011.556190.

Verhagen, T., J. van Nes, F. Feldberg, and W. van Dolen. 2014. Virtual customer service agents: Using social presence and personalization to shape online service encounters. Journal of ComputerMediated Communication 19 (3): 529-545. https://doi.org/10. $1111 /$ jcc4.12066.

Wang, E.S.-T. 2009. Displayed emotions to patronage intention: Consumer response to contact personnel performance. The Service Industries Journal 29 (3): 317-329. https://doi.org/10.1080/ 02642060701846747.

Webb, H.W., and L.A. Webb. 2004. SiteQual: An integrated measure of Web site quality. Journal of Enterprise Information Management 17 (6): 430-440. https://doi.org/10.1108/17410390410566724.

Westbrook, R.A. 1987. Product/consumption-based affective responses and postpurchase processes. Journal of Marketing Research 24 (3): 258-270. https://doi.org/10.2307/3151636.

Westbrook, R.A., and R.L. Oliver. 1991. The dimensionality of consumption emotion patterns and consumer satisfaction. Journal of Consumer Research 18 (1): 84-91. https://doi.org/10.1086/ 209243.

White, C.J. 2010. The impact of emotions on service quality, satisfaction, and positive word-of-mouth intentions over time. Journal of Marketing Management 26 (5-6): 381-394. https://doi.org/10. $1080 / 02672571003633610$.

Wiese, E., and P.P. Weis. 2020. It matters to me if you are humanExamining categorical perception in human and nonhuman agents. International Journal of Human-Computer Studies 133: 1-12. https://doi.org/10.1016/j.ijhcs.2019.08.002.
Wolfinbarger, M., and M.C. Gilly. 2003. eTailQ: Dimensionalizing, measuring and predicting Etail quality. Journal of Retailing 79 (3): 183-198. https://doi.org/10.1016/S0022-4359(03)00034-4.

Wong, A. 2004. The role of emotional satisfaction in service encounters. Managing Service Quality: An International Journal 14 (5): 365-376. https://doi.org/10.1108/09604520410557976.

Wu, C., F. Cheng, and D.C. Yen. 2008. The atmospheric factors of online storefront environment design: An empirical experiment in Taiwan. Information \& Management 45 (7): 493-498. https://doi.org/10.1016/j.im.2008.07.004.

Wu, R., and C.L. Wang. 2017. The asymmetric impact of otherblame regret versus self- blame regret on negative word of mouth: Empirical evidence from China. European. Journal of Marketing 51 (11/12): 1799-1816. https://doi.org/10.1108/ EJM-06-2015-0322.

$\mathrm{Xu}$, J.D. 2016. Retaining customers by utilizing technology-facilitated chat: Mitigating website anxiety and task complexity. Information \& Management 53 (5): 554-569. https://doi.org/ 10.1016/j.im.2015.12.007.

Xu, X., W. Liu, and D. Gursoy. 2019. The impacts of service failure and recovery efforts on airline customers' emotions and satisfaction. Journal of Travel Research 58 (6): 1034-1051. https:// doi.org/10.1177/0047287518789285.

Yapp, E., G.H. Tanakinjal, and S.L. Sondoh. 2014. The key dimensions of online service quality: A study of consumer perceptions. The IUP Journal of Marketing Management 13 (2): $7-18$.

Yi, Y., and T. Gong. 2013. Customer value co-creation behavior: Scale development and validation. Journal of Business Research 66 (9): 1279-1284. https://doi.org/10.1016/j.jbusres.2012.02.026.

Yoo, B., and N. Donthu. 2001. Developing a scale to measure the perceived quality of Internet shopping sites (SITEQUAL). Quarterly Journal of Electronic Commerce 2 (1): 31-47. https://doi.org/10. 1007/978-3-319-11885-7_129.

Young, H., and S.J. Lennon. 2010. Effects of site design on consumer emotions: Role of product involvement. Journal of Research in Interactive Marketing 4 (2): 80-96. https://doi.org/10.1108/ 17505931311316734.

Zemblytè, J. 2015. The instrument for evaluating e-service quality. Procedia - Social and Behavioral Sciences 213: 801-806. https:// doi.org/10.1016/j.sbspro.2015.11.478.

Zhao, Y., L. Yan, and H.T. Keh. 2018. The effects of employee behaviours on customer participation in the service encounter : The mediating role of customer emotions. European Journal of Marketing 52 (5/6): 1203-1222. https://doi.org/10.1108/ EJM-10-2016-0559.

Publisher's Note Springer Nature remains neutral with regard to jurisdictional claims in published maps and institutional affiliations.

Lova Rajaobelina is a Professor of Marketing at the Université du Québec à Montréal (UQAM). He is an Associate Researcher for the Financial Services Management Chair at the same university (www. chaire-msf.uqam.ca). His research interests are in experiential marketing, bank marketing, hospitality and tourism strategies, relationship marketing and online consumer marketing. His publications include journals such as Journal of Relationship Marketing, Services Industries Journal, International Journal of Bank Marketing.

Isabelle Brun is a Professor of Marketing at the Universite de Moncton. She is also an Associate Researcher of the Financial Services Management Chair at the Université du Québec à Montréal (www.chaire-msf. uqam.ca) as well as a member of the Research Group on Cooperative Management at the Université de Moncton. Her research interests are in 
bank marketing, relationship marketing, experiential marketing, online consumer marketing and consumer behavior.

Nour Kilani is a Ph.D. candidate at Université du Québec à Montréal (UQAM). Her research interests are in experiential marketing and services marketing.

Line Ricard is a Professor of Marketing at the Université du Québec à Montréal (UQAM). She is also the Director of the Financial Services Management Chair at the same university (www.chaire-msf.uqam.ca).
Her research interests are in services marketing, relationship marketing, tourism marketing, bank marketing and marketing research methodology. Her publications include journals such as Journal of Relationship Marketing, Journal of Business Research and International Journal of Bank Marketing. 